\title{
Protein Kinases Involved in the Regulation of Wnt/ $\beta$-catenin Signaling
}

\author{
Eun-Young Shin ${ }^{1,2}$, Edmond Changkyun Park', Yeonhee Hong ${ }^{1}$ and Gun-Hwa Kim ${ }^{1,2}$ * \\ ${ }^{1}$ Division of Life Science, Korea Basic Science Institute (KBSI), Dajeon 305-759, Korea \\ ${ }^{2}$ Department of Functional Genomics, University of Science and Technology (UST), Daejeon 305-350, Korea
}

Received June 29, 2013 /Revised July 5, 2013 / Accepted July 8, 2013

\begin{abstract}
The Wnt/ $\beta$-catenin signaling pathway is an evolutionarily conserved signaling network that is critical for embryonic development and adult tissue maintenance. In addition, aberrant activation of Wnt/ $\beta$ catenin signaling is implicated in the formation of various human diseases, including cancers. Thus, study of the underlying molecular mechanism of Wnt/ $\beta$-catenin signaling regulation is important to understand and treat diseases. Inhibition of aberrant Wnt pathway activity in cancer cell lines efficiently blocks their growth, highlighting the great potential of therapeutics designed to achieve this in cancer patients. Recently, protein kinases have emerged as key regulating components of Wnt/ $\beta$ -catenin signaling. In this review, we provide the most recent information on Wnt/ $\beta$-catenin signaling, describe protein kinases involved in Wnt/ $\beta$-catenin signaling, and discuss their potential as drug targets.
\end{abstract}

Key words : Wnt, $\beta$-catenin, kinase, cancer, development

Abbreviations : APC, adenomatous polyposis coli; BCL9, B-cell CLL/lymphoma 9; CBP, CREB-binding protein; CK, Casein kinase; GRK5/6, G protein-coupled receptor kinase 5/6; GSK3, Glycogen synthase kinase-3; HDAC, Histone deacetylase; HIPK2, Homeodomain interaction protein kinase 2; LEF, Lympoid enhancer-binding factor; LRP5/6, Low-density lipoprotein receptor-related protein 5/6; LMM1/2, Myeloid/Lympoid $1 / 2$ or Mixed-lineage leukemia; MAK, Metastasis-associated kinase; NLK, Nemo-like kinase; PAF1, RNA polymerase II associated factor; PKA, Protein kinase A; TCF, T-cell (specific transcription) factor; TINK, Traf2- and Nck-interacting kinase; $\beta$-TrCP, $\beta$-transducin repeat-containing protein; TRRAP, Transformation/transcription domainassociated protein.

\section{서 론}

Wnt 신호는 세포의 운명을 결정하고, 세포의 극성 및 증식 과 분화를 조절하는 세포신호전달경로로써 배아의 발생과 성 체의 항성성 유지에 필수적이다. Wnt 신호는 대표적으로 canonical Wnt 신호와 non-canonical Wnt 신호로 분류할 수 있으 며, canonical Wnt 신호는 주로 세포의 운명 결정과 증식을 조절하고 non-canonical Wnt 신호의 경우 세포의 극성을 조절 하는 것으로 알려져 있다. 이러한 Wnt 신호의 비정상적인 조 절에 의해 선천적 기형, 암, 대사 질환 등이 유발된다[3]. Wnt 신호는 1982년 처음 발견[35] 된 이래로 30년 동안 연구가 진행 되었음에도 불구하고, 아직까지 Wnt 신호를 특이적으로 조절

\footnotetext{
*Corresponding author

Tel : +82-42-865-3649, Fax : +82-42-865-3419

E-mail : genekgh@kbsi.re.kr

This is an Open-Access article distributed under the terms of the Creative Commons Attribution Non-Commercial License (http://creativecommons.org/licenses/by-nc/3.0) which permits unrestricted non-commercial use, distribution, and reproduction in any medium, provided the original work is properly cited.
}

하는 약물이 개발되지 않고 있다. 이는 지금까지 알려진 Wnt 신호 조절 인자들의 효과적이고 특이적인 기능 조절이 쉽지 않기 때문이다. 이러한 이유로 Wnt 신호를 조절하는 새로운 단백질의 발굴과 기능 연구는 아직도 중요한 연구 분야로 주 목받고 있다. 특히 최근 들어 Wnt 신호를 조절하는 인자로 인산화 단백질들(protein kinases)이 새롭게 조명 받고 있는 추세이다.

Kinase는 목표 단백질을 인산화(phosphorylation) 시키는 효소로서 목표 단백질의 활성, 구조, 세포내 위치, 다른 단백질 과의 결합을 변화시켜 목표 단백질의 기능을 조절함으로써 세포내 정보 전달에 매우 중요한 역할을 담당한다. 현재까지 약 160 여종 이상의 kinase가 암을 비롯한 다양한 질병에 관련 되어 있음이 잘 알려 있다[59]. 특히 kinase는 단백질 활성의 조절과 특이적 활성/비활성제 약물의 개발이 비교적 쉬워서 신약 개발의 주요 대상이 되고 있다. 본 총설에서는 canonical Wnt/ $\beta$-catenin 신호를 조절하는 kinase의 기능에 대해서 알 아보고 약물 개발 목표 대상으로써의 활용 가능성에 대해서 기술하고자 한다. 


\section{Wnt/ $\beta$-catenin 신호 전달 경로}

Wnt/ $\beta$-catenin 신호는 세포질에 존재하는 $\beta$-catenin 단백 질을 안정화 시켜 목표 유전자의 전사를 유도하는 세포신호전 달경로이다. Wnt 신호가 없는 경우 $\beta$-catenin은 Axin/APC/ GSK3/CK1으로 이루어진 $\beta$-catenin destruction complex에 의해 인산화된다. 인산화된 $\beta$-catenin은 E3 ubiquitin ligase인 $\beta-\operatorname{TrCP}$ 에 의해 ubiquitination 된 후 proteasome에 의해 분해 된다(Fig. 1A). 그러나 Wnt ligand가 막수용체인 Frizzled와 LRP5/6에 결합하면 $\beta$-catenin은 더 이상 분해되지 않고 세포 내에 축적되고, 안정화된 $\beta$-catenin은 핵 내부로 들어가서 목 표 유전자의 전사를 유도한다. 이러한 Wnt 신호에 의한 세포 질 내 $\beta$-catenin의 안정화는 $\beta$-catenin destruction complex의 결합이 와해되어 CK1과 GSK3가 더 이상 $\beta$-catenin을 인산화 시키지 못하여 이루어진다고 여겨져 왔다(Fig. 1B)[31].

그러나 최근 연구 결과에 의하면, Wnt 신호에 의한 $\beta$ -catenin의 안정화를 세포 내재적인(endogenous) 수준에서 관 찰하였을 때 $\beta$-catenin destruction complex의 결합이 와해되 지 않고 그대로 유지되어 있으면서 세포 내 위치가 바뀜으로 써 $\beta$-catenin의 안정화가 유도된다고 새롭게 밝혀졌다. 즉, $\beta$ catenin destruction complex에 의한 $\beta$-catenin의 인산화에는 변화가 없으나, Wnt 신호에 의해 $\beta$-catenin destruction complex가 세포질에서 세포막으로 이동하여 Frizzled, LRP5/6 수용체와 결합한 상태로 존재함으로써 세포질에 존 재하는 $\beta-\operatorname{TrCP}$ 가 인산화된 $\beta$-catenin을 인식하지 못하게 되 어 $\beta$-catenin destruction complex와 결합된 $\beta$-catenin을 분해 시키지 못하게 된다는 것이다. 이로 인해 $\beta$-catenin destruction complex가 포화된 상태가 되어 새로 발현된 $\beta$-catenin이 분해 되지 않고 세포질 내에 축적되어 Wnt 신호가 전달된다(Fig. 1C)[28].

이렇게 안정화된 $\beta$-catenin은 핵 내부로 들어가서 $\mathrm{TCF}$ 전사 인자와 결합하여 전사를 억제하고 있는 Groucho/HDAC을 분리시키고, BCL9/Pygopus와 함께 $\mathrm{TCF}$ 에 결합한다. 동시에 p300/CBP, TRRAP/TIP60, MLL1/2, BRG1, PAF1 등과 같은 chromatin remodeling complex와 함께 작용하여 목표 유전자 의 전사를 유도한다(Fig. 1)[34, 51]. 이러한 조절 기작 이외에도 $\mathrm{Wnt} / \beta$-catenin 신호는 여러 단계에서 다양한 kinase에 의해 조절 받고 있다. 따라서 아래에서는 주요 Wnt 신호 전달 단백 질을 인산화 시키는 kinase의 종류와 작용 기작에 대해 간단히 소개하고자 한다(Table 1).

\section{Kinase에 의한 Wnt/ $\beta$-catenin 신호 조절}

$\mathrm{LRP} 5 / 6$ 을 인산화 시키는 kinase

Wnt/ $\beta$-catenin 신호는 Wnt ligand가 Frizzled와 LRP5/6 막수용체에 결합 함으로써 시작된다. LRP6의 cytoplasmic domain에는 proline-rich PPPSP motif와 CK1 site가 병렬로 짝을 이루어 5 번 반복되어 있다. 이 두 자리의 인산화는 $\beta$ -catenin의 안정화와 Wnt 신호 목표 유전자의 전사를 유도한 다[44, 58]. LRP를 인산화 시키는 kinase는 인산화 시키는 위치 에 따라 proline-directed kinase (GSK3, PKA, PFTK1, GRK5/6)와 non-proline-directed kinase (CK1)로 구분할 수 있다.

GSK3는 Ser/Thr kinase로써 $\beta$-catenin destruction complex의 안정화와 $\beta$-catenin의 인산화를 유도하여 Wnt 신 호전달을 억제한다고 알려져 있다[3]. 그러나 Wnt 신호가 오 면 GSK3는 LRP6를 인산화 시켜 Wnt/ $\beta$-catenin 신호를 활성 화 시키는 역할도 수행한다. 이러한 GSK3에 의한 Wnt 신호의 활성화는 LRP6의 PPPSP motif를 인산화 시킴으로써 Axin의 결합을 유도하여 일어난다[58].

PKA는 cAMP-dependent Ser/Thr kinase로써 Wnt ligand 와는 독립적으로 parathyroid hormone $(\mathrm{PTH})$ 에 의해 활성화 되며, LRP6를 인산화 시킴으로써 PTH 신호와 Wnt/ $\beta$-catenin 신호를 활성화 시킨다[48]. 또한 PKA는 골아세포(osteoblastic cell) Saos-2에서 GSK3를 억제함으로써 Wnt/ $\beta$-catenin 신호 를 활성화 시킨다고 보고되어있다[42].

PFTK1는 세포주기를 조절하는 cyclin-dependent kinase $(\mathrm{CDK})$ 로써 $\mathrm{G} 2 / \mathrm{M}$ 기에 $\mathrm{LRP}$ 를 인산화 시킴으로써 $\mathrm{Wnt} / \beta$ -catenin 신호를 활성화 시키며, Wnt/ $\beta$-catenin 신호의 목표 유전자의 발현 조절 뿐만 아니라 세포 분열의 조절에도 중요 한 기능을 담당한다[6].

GRK5/6는 membranes associated kinase로써 G-protein coupled receptor kinase (GRK) family에 속하며, LRP6의 PPPSP motif를 인산화 시킴으로 Wnt/ $\beta$-catenin 신호를 활성 화 시키는 것으로 알려져 있다[2].

CK1은 Ser/Thr kinase로써 네 가지 isoform들(CK1, a, $\delta$, ع)이 존재한다. CK1은 Wnt 신호전달경로 전반에 걸쳐 작용하 는 kinase로써 인산화 목표 단백질의 종류와 인산화 위치에 따라 Wnt 신호를 활성화 시키기도 하고 억제 시키기도 한다. $\mathrm{CK} 1 \mathrm{\gamma}$ 는 다른 CK1 isoform들과 달리 세포막에 위치하며, LRP 의 인산화(T1479, T1493)를 통해 Axin을 세포막으로 이동시켜 Wnt/ $\beta$-catenin 신호를 활성화 시킨다[7]. CK1a, $\delta, \varepsilon$ 은 LRP의 $\mathrm{T} 1493$ 을 인산화 시켜 Wnt/ $\beta$-catenin 신호를 활성화 시킨다 $[6$, $36,58,60]$. 반면 CK1이 이의 S1420, S1430을 인산화 시키는 경우 Wnt/ $\beta$-catenin 신호가 억제 된다는 보고도 있다[43]. 그 러나 이러한 각기 다른 Wnt 신호의 조절이 정확히 어떠한 기 작을 통해서 이루어지는지는 아직 밝혀지지 않았다.

\section{Axin, $\mathrm{APC}$ 를 인산화 시키는 kinase}

$\beta$-catenin destruction complex의 뼈대라 할 수 있는 scaffold 단백질인 Axin은 $\mathrm{APC}, \mathrm{CK} 1 \mathrm{a}, \beta$-catenin등과 직접적 으로 결합한다(Fig. 1A)[30]. 결합 된 $\beta$-catenin destruction 
Table 1. List of protein kinase that regulates $W n t / \beta$-catenin signaling pathway

\begin{tabular}{|c|c|c|c|c|c|c|}
\hline Target protein & Kinase & & osphorylation site & $\begin{array}{l}\text { Regulation in } \\
\text { Wnt signaling }\end{array}$ & Features & References \\
\hline \multirow{7}{*}{ LRP6 } & CK1 $\gamma$ & & T1479/T1493 & $t^{\mathrm{a}}$ & $\begin{array}{l}\text { Wnt-inducible, } \\
\text { Dvl, PI4KIIa, PIP5KI dependent }\end{array}$ & {$[1,7]$} \\
\hline & $\mathrm{CK} 1 \mathrm{a}, \delta, \varepsilon$ & & T1493 & + & Wnt-inducible & {$[6,36,58,60]$} \\
\hline & $\mathrm{CK} 1 \varepsilon$ & & S1420/S1430 & $-{ }^{b}$ & upstream of LRP6 & [43] \\
\hline & GSK3 & & $\begin{array}{l}\text { 490/T1530/T1530 } \\
1572 / \mathrm{S} 1590 / \mathrm{S} 1607\end{array}$ & + & $\begin{array}{l}\text { Wnt-inducible,PI4KIIa, PIP5KI dependent } \\
\text { Axin, Dvl, Fz dependent }\end{array}$ & {$[32,36,57,58]$} \\
\hline & GRK5/6 & & $\begin{array}{l}\text { 490/T1530/T1572 } \\
\text { /S1590/S1607 }\end{array}$ & + & $\begin{array}{l}\text { Wnt acute reaction } \\
\text { phosphorylation in PPPSP repeat }\end{array}$ & [2] \\
\hline & PKA & & S1490 & + & PTH inducible, Wnt independent & [48] \\
\hline & PFTK1 & & S1490 & + & likely Wnt independent & [6] \\
\hline \multirow{2}{*}{ Axin } & CK1 & & $\mathrm{n} / \mathrm{a}^{\mathrm{c}}$ & - & stabilizing of destruction complex & [10] \\
\hline & GSK3 & & S330/T341/S343 & - & stabilizing of destruction complex & {$[20,55]$} \\
\hline \multirow{2}{*}{$\mathrm{APC}$} & $\mathrm{CK} 1 \varepsilon$ & & S1279/S1392 & - & increase affinity for $\beta$-catenin & [38] \\
\hline & GSK3 & & $\mathrm{n} / \mathrm{a}$ & - & increase affinity for $\beta$-catenin & [37] \\
\hline \multirow{7}{*}{ Dishevelled } & CK1 $\delta$ & & S594/T595/S597 & + & Wnt-inducible & {$[11,33]$} \\
\hline & CK1ع & & S139/S142 & + & Wnt-inducible & {$[4,26]$} \\
\hline & CK2 & & $\mathrm{n} / \mathrm{a}$ & + & Wnt-inducible & {$[50]$} \\
\hline & MAK & & $\mathrm{n} / \mathrm{a}$ & - & $\begin{array}{l}\text { inhibits the canonical Wnt pathway and } \\
\text { upregulates non-canonical Wnt signaling }\end{array}$ & [24] \\
\hline & PAR-1 & & $\mathrm{n} / \mathrm{a}$ & + & $\begin{array}{l}\text { positive regulator of the } \beta \text {-catenin pathway } \\
\text { and inhibitor of the JNK pathway }\end{array}$ & [41] \\
\hline & PLK1 & & $\mathrm{n} / \mathrm{a}$ & + & likely Wnt-independent & [25] \\
\hline & RIPK4 & & S298/S480 & + & Wnt-inducible & [19] \\
\hline \multirow{7}{*}{$\beta$-catenin } & AKT & & S552 & + & stabilizing of $\beta$-catenin & [46] \\
\hline & CK1a & & S45 & - & priming phosphorylation for GSK3 & [56] \\
\hline & CK2 & & T393 & + & leading to proteasome resistance & [40] \\
\hline & GSK3 & & S41/S37/S33 & - & CK1-dependent & [29] \\
\hline & JNK2 & & S191/S605 & + & $\begin{array}{l}\text { induce the nuclear accumulation of } \beta \\
\text {-catenin }\end{array}$ & [53] \\
\hline & PKA & & S552/S675 & + & stabilizing of $\beta$-catenin & {$[23,45]$} \\
\hline & PKC & & S33/S37/S45 & - & $\begin{array}{l}\text { Ca2+, lipid activator dependent without } \\
\text { requiring a priming kinase such as CK1a or } \\
\text { PKA }\end{array}$ & [12] \\
\hline \multirow{10}{*}{$\mathrm{TCF} / \mathrm{LEF}$} & CK1 $\delta$ & LEF1 & S42 & - & disruption of $\beta$-catenin-Lef1 complex & [13] \\
\hline & CK1ع & & $\mathrm{n} / \mathrm{a}$ & + & $\begin{array}{l}\text { increase binding affinity of } \beta \text {-catenin } \\
\text { decrease binding affinity of Groucho }\end{array}$ & [27] \\
\hline & CK2 & LEF1 & S42/S61 & + & $\begin{array}{l}\text { increase binding affinity of } \beta \text {-catenin } \\
\text { decrease binding affinity of Groucho }\end{array}$ & [49] \\
\hline & \multirow{3}{*}{ HIPK2 } & LEF1 & S132/T155/S166 & \multirow{3}{*}{+} & \multirow{3}{*}{ Tcf3, Tcf1 exchange } & \multirow{3}{*}[21,22]{} \\
\hline & & TCF3 & $\begin{array}{l}\text { S169/S171/T192/ } \\
\text { S203/S212 }\end{array}$ & & & \\
\hline & & TCF4 & $\begin{array}{c}\text { S154/S156/T178/ } \\
\mathrm{T} 188\end{array}$ & & & \\
\hline & \multirow{2}{*}{ NLK } & LEF1 & T155/S166 & \multirow{2}{*}{ - } & \multirow{2}{*}{$\begin{array}{l}\text { disrupt a binding of TCF, } \beta \text {-catenin complex } \\
\text { on DNA increase of LEF1/TCF } 4 \text { degradation } \\
\text { increase nuclear exprot of TCF, } \beta \text {-catenin } \\
\text { complex }\end{array}$} & \multirow{2}{*}{ [16] } \\
\hline & & TCF4 & T178/T189 & & & \\
\hline & \multirow{2}{*}{ TINK } & TCF3 & S169 & \multirow{2}{*}{+} & \multirow{2}{*}{ recruited by $\beta$-catenin } & \multirow{2}{*}{ [39] } \\
\hline & & TCF4 & S154 & & & \\
\hline
\end{tabular}

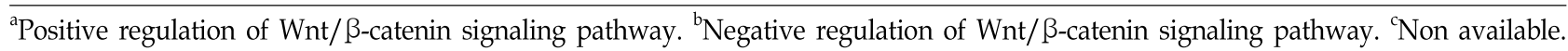




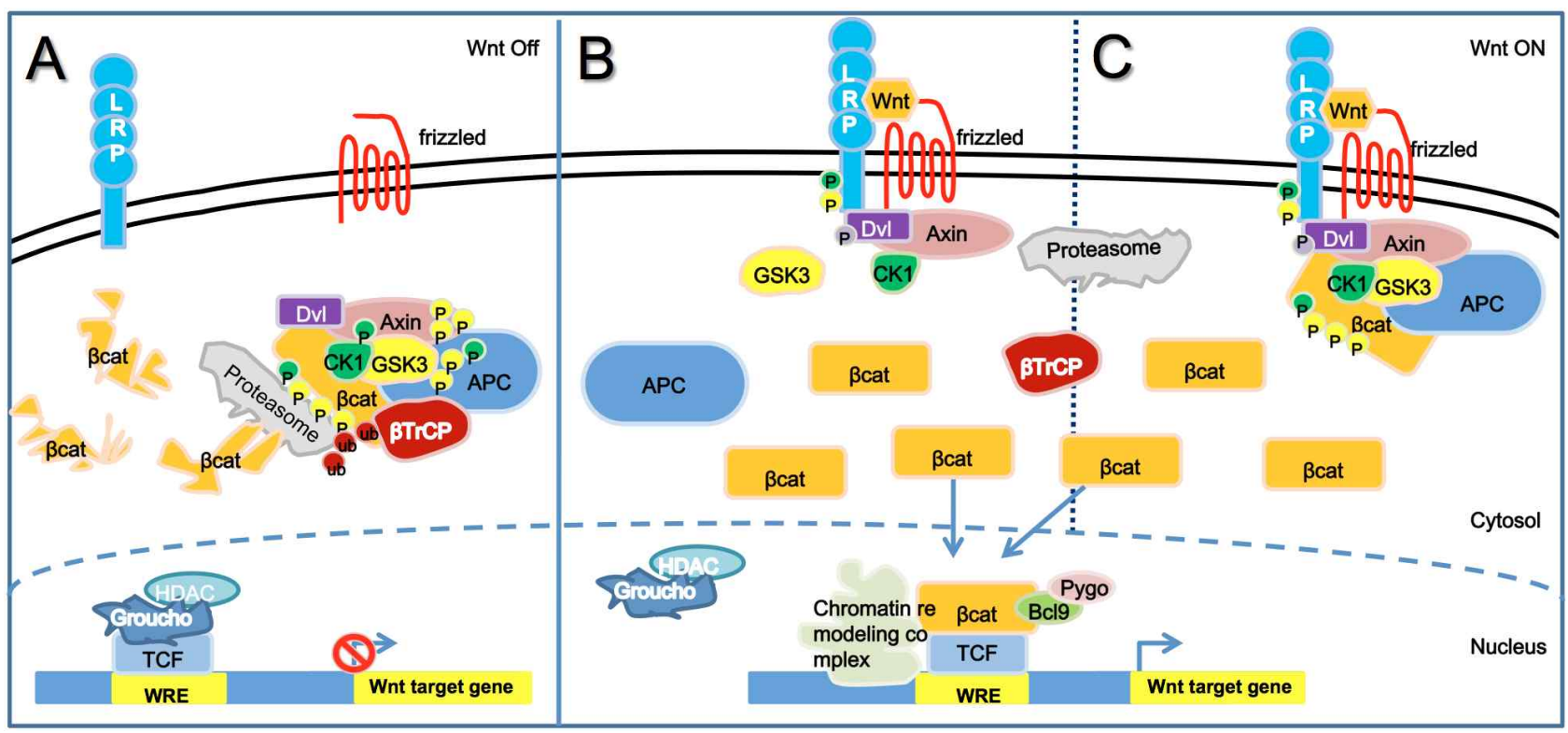

Fig. 1. Wnt/ $\beta$-catenin signaling pathway. (A) $\beta$-catenin destruction complex. In the absence of signal, $\beta$-catenin is phosphrylated by CK1 and CSK3, which triggers ubiquitination and proteosomal degradation. (B) Previous model of $\beta$-catenin destruction complex. Binding of Wnt ligand to Frizzled and LRP5/6 receptor leads to disruption of $\beta$-catenin destruction complex, and $\beta$-catenin is no longer degraded. (C) New model of $\beta$-catenin destruction complex. When Wnt ligand binds to receptor complex, $\beta$-catenin destruction complex is translocated to plasma membrane to interact with ligand/receptor complex, but not to be disrupted. This blocks ubiquitination of $\beta$-catenin by $\beta$-TrCP and newly synthesized $\beta$-catenin is accumulated.

complex는 $\beta$-catenin의 분해를 촉진하며, 이는 Axin의 인산화 /탈인산화에 영향을 받는다[18]. Axin이 과인산화 되거나 탈 인산화 되면 $\beta$-catenin destruction complex를 이루지 못하여 $\beta$-catenin이 축적되고 $\mathrm{Wnt} / \beta$-catenin 신호가 활성화 된다 $[52$, 55]. 그러나 CK1, GSK3에 의해 인산화 된 Axin은 $\beta$-catenin destruction complex의 안정성을 높여 $\beta$-catenin의 인산화를 크게 증가시켜 $\mathrm{Wnt}$ 신호를 차단한다 $[5,20]$. Axin과 함게 $\beta$-catenin destruction complex를 이루는 APC도 CK1과 GSK3에 의해 인산화 되어 $\beta$-catenin destruction complex의 안정화에 관여하며 $[37,38]$, 이미 인산화 된 $\beta$-catenin을 destruction complex로 부터 분리시켜 새로운 $\beta$-catenin이 destruction complex 내로 결합할 수 있는 공간을 만드는 역할도 수행한다 [54].

\section{Dishevelled (Dv//Dsh)를 인산화 시키는 kinase}

Dvl는 canonical Wnt/ $\beta$-catenin 신호전달경로뿐 만 아니라 non-canonical Wnt 신호전달경로 모두에 작용하는 신호전달 의 중심 단백질이다[31]. Canonical Wnt 신호전달경로에서 Dvl은 Axin과 GSK3 3 complex를 Frizzled/LRP 막수용체로 이끌어 와서 Wnt 신호를 활성화 시키는 역할을 한다[57]. Dvl 은 DIX, PDZ, DEP 세 개의 domain으로 구성되어 있으며, $\mathrm{PDZ}$ 와 $\mathrm{DEP}$ domain에 인산화 사이트가 많이 존재한다고 알
져 있고, 각 인산화 사이트는 Wnt 신호가 존재할 때 특정 kinase에 의해 인산화 된다[47]. 그러나 Dvl의 인산화와 $\mathrm{Wnt} / \beta$ -catenin 신호 활성 사이의 정확한 기작은 아직 완벽히 밝혀지 지 않았다.

$\mathrm{CK} 1$ 과 $\mathrm{CK} 1 \delta$ 는 Dvl에 결합하여 인산화 시킴으로써 Wnt/ $\beta$-catenin 신호를 활성화 시킨다. 현재까지 알려진 CK1\&의 인 산화 사이트(S139, S132)를 인산화 되지 못하도록 돌연변이 시 켜도 Dvl 활성에는 변화가 없는 것으로 미루어 보아 Dvl 활성 을 조절하는 추가적인 $\mathrm{CK} 1$ 인산화 사이트가 존재 할 것으로 생각된다[26]. CK2도 Dvl과 결합하여 Dvl을 인산화 시키는 것으로 보고 되었으나[50], 반대로 Dv1에 의해 CK2의 활성이 조절 된다는 보고도 있다[9]. 따라서 Dvl과 CK 사이의 상호 기능 조절에 대해 정확한 연구가 필요한 상황이다.

PAR-1은 Dsh-associated kinase로 처음 밝혀 졌으며 Dvl의 $\mathrm{PDZ}$ 도메인을 인산화 시켜 Wnt/ $\beta$-catenin 신호를 활성화 시 키는 것으로 알려져 있다[41]. 가장 최근에 보고된 kinase인 RIPK4는 Wnt 신호의 존재 유무에 상관없이 Dvl에 결합하고 있으며, Wnt 신호에 의해 Dvl을 인산화 시켜서 Wnt/B-catenin 신호를 활성화 시키는 작용을 한다[19].

이와는 반대로 MAK는 dvl를 인산화 시켜 canonical Wnt/ $\beta$-catenin 신호를 억제하고 non-canonical Wnt 신호를 활성화 시킨다고 알려져 있다[24]. 


\section{$\beta$-catenin을 인산화 시키는 kinase}

$\beta$-catenin은 Wnt 신호가 없을 때 $\beta$-catenin destruction complex의 CK1에 의해 먼저 $\mathrm{S} 45$ 가 인산화되고, 그 이후에 $\mathrm{GSK} 3 / \mathrm{PKC}$ 에 의해 $\mathrm{T} 41, \mathrm{~S} 37, \mathrm{~S} 33$ 이 차례로 인산화되는 조절 을 받는다 $[29,56]$. 인산화된 $\beta$-catenin은 $\beta-\operatorname{TrCP}$ 에 의해 ubiquitination 된 후 분해되어 Wnt 신호를 전달하지 못한다[14]. 반대로 $\beta$-catenin의 인산화는 Wnt 신호의 활성화에도 관여 된다. Wnt 신호에 의해서 안정화된 $\beta$-catenin의 경우 $\mathrm{AKT}$ 와 $\mathrm{PKA}$ 에 의해 인산화되어 $\mathrm{CBP}$ 와 같은 전사 활성화 인자들과 결합하여 목표 유전자를 전사 시킨다 $[8,17,46]$. 또한 JNK2도 $\beta$-catenin을 인산화 시킴으로써 Wnt/ $\beta$-catenin 신호의 활성 화에 기여한다[53]. 그러나 이러한 인산화를 통한 $\beta$-catenin의 활성화는 Wnt 신호의 독립적인 역할이 아닌 아른 신호전달경 로와의 cross-talk에 의한 것으로 여겨진다.

\section{TCF/LEF를 인산화 시키는 kinase}

Wnt 신호에 의해 안정화된 $\beta$-catenin은 핵으로 들어가서 $\mathrm{TCF}$ 전사 인자와 결합하여 목표 유전자를 발현시킨다. 이 과 정에서 $\mathrm{CK} 1 \varepsilon$ 과 $\mathrm{CK} 2$ 는 $\mathrm{TCF} 3$ 와 $\mathrm{LEF} 1$ 을 각각 인산화 시켜 $\mathrm{TCF} / \mathrm{LEF}$ 와 $\beta$-catenin과의 결합력을 높이는 동시에 전사 억제 인자인 Groucho와의 결합은 억제 시켜 Wnt 신호에 의한 목표 유전자 전사를 유도한다[27, 49]. 반면 CK1 $\delta$ 의 경우 LEF1과 $\beta$-catenin의 결합을 저해하여 Wnt 신호를 억제한다는 보고도 있다[13].

$\mathrm{NLK}$ 의 경우 LEF1과 TCF4에 결합하여 $\mathrm{TCF} / \beta$-catenin complex가 DNA에 결합하는 것을 억제하며, complex를 핵 밖으로 내보내거나 LEF/TCF 단백질의 분해를 유도하여 Wnt 신호의 활성을 감소시키는 역할을 한다[21, 22].

HIPK2경우 DNA의 Wnt response element (WRE)에 결합 하고 있는 $\mathrm{TCF}$ 의 종류를 바꾸는데 관여한다. Wnt 신호가 없 을 때에는 WRE에 TCF3가 결합되어 다른 co-repressor들과 함께 목표 유전자의 전사를 억제한다. Wnt 신호가 오게 되면 $\mathrm{HIPK} 2$ 가 TCF3를 인산화 시켜 WRE와의 결합을 저해하고, 동 시에 TCF1이 WRE에 새롭게 결합함으로써 Wnt 목표 유전자 의 전사가 활성화 된다 $[15,16]$. TINK도 $\beta$-catenin에 의존적으 로 WRE에 결합하고 있는 TCF3/4를 인산화 시켜 TCF/LEF 교환에 관여하여 Wnt 신호의 활성화를 유도한다[39].

\section{결 론}

이상에서 기술 한 바와 같이 Wnt/ $\beta$-catenin 신호는 다양한 kinase들에 의해 신호 전달 단계에서 복잡하게 조절되고 있다. 현재까지 Wnt/ $\beta$-catenin 신호를 조절하는 여러가지 kinase들 이 알려지고 그 작용 기작이 보고 되었으나, 여전히 해결해야 할 과제도 많이 남아 있다. 특히 한 종류의 kinase가 여러 개의 $\mathrm{Wnt} / \beta$-catenin 신호전달경로 인자의 인산화에 관여된 경우
정확한 Wnt 신호 조절 기작과 생채 내 기능에 대한 연구가 많이 미흡한 실정이다. 예를 들어 CK와 GSK3의 경우 종류와 인산화 목표에 따라 Wnt 신호가 매우 다양하게 조절할 수 있 음을 확인 하였다. 따라서 kinase의 종류와 인산화 사이트에 따라 어떤 생명 현상에서 Wnt/ $\beta$-catenin 신호를 어떻게 조절 하는지 보다 명확히 이해할 필요가 있다. 또한 Wnt/ $\beta$-catenin 신호에 관련된 kinase의 활성을 조절하는 상위 신호나 조절자 에 대한 정보 및 Wnt/ $\beta$-catenin 신호와의 연관성에 대한 정보 가 매우 부족하므로, 정확한 Wnt/ $\beta$-catenin 신호 조절 기작의 이해를 위한 다양한 연구가 필요하다. 이 외에도 기술된 kinase들과 관련된 여러 가지 질병에서 Wnt/ $\beta$-catenin 신호의 역할과, 약물을 이용한 kinase의 활성과 Wnt/ $\beta$-catenin 신호 조절을 통한 질병의 완화 및 치료에 대한 연구도 필요하다. 대표적인 예로 최근 Dvl를 인산화 시키는 RIPK4의 발현 억제 를 통해 Wnt 신호와 관련된 질병이 완화되었음을 보여준 연구 가 있다[19]. 따라서 Wnt/ $\beta$-catenin 신호를 조절하는 새로운 kinase를 찾고 발생과정과 질병에서의 작용 기전을 밝히는 연 구도 더욱 활발히 이루어져야 할 것이다.

\section{Acknowledgment}

본 연구는 한국기초과학지원연구원의 지원을 받아 수행되 었습니다(과제번호: T33609 \& PBC074).

\section{References}

1. Bilic, J., Huang, Y. L., Davidson, G., Zimmermann, T., Cruciat, C. M., Bienz, M. and Niehrs, C. 2007. Wnt induces LRP6 signalosomes and promotes dishevelled-dependent LRP6 phosphorylation. Science 316, 1619-1622.

2. Chen, M., Philipp, M., Wang, J., Premont, R. T., Garrison, T. R., Caron, M. G., Lefkowitz, R. J. and Chen, W. 2009. G Protein-coupled receptor kinases phosphorylate LRP6 in the Wnt pathway. J Biol Chem 284, 35040-35048.

3. Clevers, H. and Nusse, R. 2012. Wnt/beta-catenin signaling and disease. Cell 149, 1192-1205.

4. Cong, F., Schweizer, L. and Varmus, H. 2004. Casein kinase Iepsilon modulates the signaling specificities of dishevelled. Mol Cell Biol 24, 2000-2011.

5. Dajani, R., Fraser, E., Roe, S. M., Yeo, M., Good, V. M., Thompson, V., Dale, T. C. and Pearl, L. H. 2003. Structural basis for recruitment of glycogen synthase kinase 3beta to the axin-APC scaffold complex. EMBO J 22, 494-501.

6. Davidson, G., Shen, J., Huang, Y. L., Su, Y., Karaulanov, E., Bartscherer, K., Hassler, C., Stannek, P., Boutros, M. and Niehrs, C. 2009. Cell cycle control of wnt receptor activation. Dev Cell 17, 788-799.

7. Davidson, G., Wu, W., Shen, J., Bilic, J., Fenger, U., Stannek, P., Glinka, A. and Niehrs, C. 2005. Casein kinase 1 gamma couples Wnt receptor activation to cytoplasmic signal 
transduction. Nature 438, 867-872.

8. Fang, D., Hawke, D., Zheng, Y., Xia, Y., Meisenhelder, J., Nika, H., Mills, G. B., Kobayashi, R., Hunter, T. and Lu, Z. 2007. Phosphorylation of beta-catenin by AKT promotes beta-catenin transcriptional activity. J Biol Chem 282, 1122111229.

9. Gao, Y. and Wang, H. Y. 2006. Casein kinase 2 Is activated and essential for Wnt/beta-catenin signaling. J Biol Chem 281, 18394-18400.

10. Gao, Z. H., Seeling, J. M., Hill, V., Yochum, A. and Virshup, D. M. 2002. Casein kinase I phosphorylates and destabilizes the beta-catenin degradation complex. Proc Natl Acad SCi USA 99, 1182-1187.

11. Gonzalez-Sancho, J. M., Greer, Y. E., Abrahams, C. L., Takigawa, Y., Baljinnyam, B., Lee, K. H., Lee, K. S., Rubin, J. S. and Brown, A. M. 2013. Functional consequences of Wnt-induced dishevelled 2 phosphorylation in canonical and noncanonical Wnt signaling. J Biol Chem 288, 9428-9437.

12. Gwak, J., Cho, M., Gong, S. J., Won, J., Kim, D. E., Kim, E. Y., Lee, S. S., Kim, M., Kim, T. K., Shin, J. G. and Oh, S. 2006. Protein-kinase-C-mediated beta-catenin phosphorylation negatively regulates the $\mathrm{Wnt} /$ beta-catenin pathway. J Cell Sci 119, 4702-4709.

13. Hammerlein, A., Weiske, J. and Huber, O. 2005. A second protein kinase CK1-mediated step negatively regulates Wnt signalling by disrupting the lymphocyte enhancer factor-1/beta-catenin complex. Cell Mol Life Sci 62, 606-618.

14. Hart, M., Concordet, J. P., Lassot, I., Albert, I., del los Santos, R., Durand, H., Perret, C., Rubinfeld, B., Margottin, F., Benarous, R. and Polakis, P. 1999. The F-box protein beta-TrCP associates with phosphorylated beta-catenin and regulates its activity in the cell. Curr Biol 9, 207-210.

15. Hikasa, H., Ezan, J., Itoh, K., Li, X., Klymkowsky, M. W. and Sokol, S. Y. 2010. Regulation of TCF3 by Wnt-dependent phosphorylation during vertebrate axis specification. Dev Cell 19, 521-532.

16. Hikasa, H. and Sokol, S. Y. 2011. Phosphorylation of TCF proteins by homeodomain-interacting protein kinase 2. J Biol Chem 286, 12093-12100.

17. Hino, S., Tanji, C., Nakayama, K. I. and Kikuchi, A. 2005. Phosphorylation of beta-catenin by cyclic AMP-dependent protein kinase stabilizes beta-catenin through inhibition of its ubiquitination. Mol Cell Biol 25, 9063-9072.

18. Huang, H. and He, X. 2008. Wnt/beta-catenin signaling: new (and old) players and new insights. Curr Opin Cell Biol 20, 119-125.

19. Huang, X., McGann, J. C., Liu, B. Y., Hannoush, R. N., Lill, J. R., Pham, V., Newton, K., Kakunda, M., Liu, J., Yu, C., Hymowitz, S. G., Hongo, J. A., Wynshaw-Boris, A., Polakis, P., Harland, R. M. and Dixit, V. M. 2013. Phosphorylation of Dishevelled by protein kinase RIPK4 regulates Wnt signaling. Science 339, 1441-1445.

20. Ikeda, S., Kishida, S., Yamamoto, H., Murai, H., Koyama, S. and Kikuchi, A. 1998. Axin, a negative regulator of the Wnt signaling pathway, forms a complex with GSK-3beta and beta-catenin and promotes GSK-3beta-dependent phos- phorylation of beta-catenin. EMBO J 17, 1371-1384.

21. Ishitani, T., Ninomiya-Tsuji, J. and Matsumoto, K. 2003. Regulation of lymphoid enhancer factor 1/T-cell factor by mitogen-activated protein kinase-related Nemo-like kinase-dependent phosphorylation in Wnt/beta-catenin signaling. Mol Cell Biol 23, 1379-1389.

22. Ishitani, T., Ninomiya-Tsuji, J., Nagai, S., Nishita, M., Meneghini, M., Barker, N., Waterman, M., Bowerman, B., Clevers, H., Shibuya, H. and Matsumoto, K. 1999. The TAK1-NLK-MAPK-related pathway antagonizes signalling between beta-catenin and transcription factor TCF. Nature 399, 798-802.

23. Kang, D. E., Soriano, S., Xia, X., Eberhart, C. G., De Strooper, B., Zheng, H. and Koo, E. H. 2002. Presenilin couples the paired phosphorylation of beta-catenin independent of axin: implications for beta-catenin activation in tumorigenesis. Cell 110, 751-762.

24. Kibardin, A., Ossipova, O. and Sokol, S. Y. 2006. Metastasis-associated kinase modulates Wnt signaling to regulate brain patterning and morphogenesis. Development 133, 2845-2854

25. Kikuchi, K., Niikura, Y., Kitagawa, K. and Kikuchi, A. 2010. Dishevelled, a Wnt signalling component, is involved in mitotic progression in cooperation with Plk1. EMBO J 29, 3470-3483.

26. Klimowski, L. K., Garcia, B. A., Shabanowitz, J., Hunt, D. F. and Virshup, D. M. 2006. Site-specific casein kinase 1epsilon-dependent phosphorylation of Dishevelled modulates beta-catenin signaling. FEBS J 273, 4594-4602.

27. Lee, E., Salic, A. and Kirschner, M. W. 2001. Physiological regulation of [beta]-catenin stability by Tcf3 and CK1epsilon. J Cell Biol 154, 983-993.

28. Li, V. S., Ng, S. S., Boersema, P. J., Low, T. Y., Karthaus, W. R., Gerlach, J. P., Mohammed, S., Heck, A. J., Maurice, M. M., Mahmoudi, T. and Clevers, H. 2012. Wnt signaling through inhibition of beta-catenin degradation in an intact Axin1 complex. Cell 149, 1245-1256.

29. Liu, C., Li, Y., Semenov, M., Han, C., Baeg, G. H., Tan, Y., Zhang, Z., Lin, X. and He, X. 2002. Control of beta-catenin phosphorylation/degradation by a dual-kinase mechanism. Cell 108, 837-847.

30. Luo, W. and Lin, S. C. 2004. Axin: a master scaffold for multiple signaling pathways. Neurosignals 13, 99-113.

31. MacDonald, B. T., Tamai, K. and He, X. 2009. Wnt/beta-catenin signaling: components, mechanisms, and diseases. Dev Cell 17, 9-26.

32. MacDonald, B. T., Yokota, C., Tamai, K., Zeng, X. and He, X. 2008. Wnt signal amplification via activity, cooperativity, and regulation of multiple intracellular PPPSP motifs in the Wnt co-receptor LRP6. J Biol Chem 283, 16115-16123.

33. McKay, R. M., Peters, J. M. and Graff, J. M. 2001. The casein kinase I family in Wnt signaling. Dev Biol 235, 388-396.

34. Mosimann, C., Hausmann, G. and Basler, K. 2009. Beta-catenin hits chromatin: regulation of Wnt target gene activation. Nat Rev Mol Cell Biol 10, 276-286.

35. Nusse, R. and Varmus, H. E. 1982. Many tumors induced 
by the mouse mammary tumor virus contain a provirus integrated in the same region of the host genome. Cell 31, 99-109.

36. Pan, W., Choi, S. C., Wang, H., Qin, Y., Volpicelli-Daley, L., Swan, L., Lucast, L., Khoo, C., Zhang, X., Li, L., Abrams, C. S., Sokol, S. Y. and Wu, D. 2008. Wnt3a-mediated formation of phosphatidylinositol 4,5-bisphosphate regulates LRP6 phosphorylation. Science 321, 1350-1353.

37. Rubinfeld, B., Albert, I., Porfiri, E., Fiol, C., Munemitsu, S. and Polakis, P. 1996. Binding of GSK3beta to the APC-beta-catenin complex and regulation of complex assembly. Science 272, 1023-1026.

38. Rubinfeld, B., Tice, D. A. and Polakis, P. 2001. Axin-dependent phosphorylation of the adenomatous polyposis coli protein mediated by casein kinase 1epsilon. J Biol Chem 276, 39037-39045.

39. Satow, R., Shitashige, M., Jigami, T., Honda, K., Ono, M., Hirohashi, S. and Yamada, T. 2010. Traf2- and Nck-interacting kinase is essential for canonical Wnt signaling in Xenopus axis formation. J Biol Chem 285, 26289-26294.

40. Song, D. H., Dominguez, I., Mizuno, J., Kaut, M., Mohr, S. C. and Seldin, D. C. 2003. CK2 phosphorylation of the armadillo repeat region of beta-catenin potentiates Wnt signaling. J Biol Chem 278, 24018-24025.

41. Sun, T. Q., Lu, B., Feng, J. J., Reinhard, C., Jan, Y. N., Fantl, W. J. and Williams, L. T. 2001. PAR-1 is a Dishevelled-associated kinase and a positive regulator of Wnt signalling. Nat Cell Biol 3, 628-636.

42. Suzuki, A., Ozono, K., Kubota, T., Kondou, H., Tachikawa, K. and Michigami, T. 2008. PTH/cAMP/PKA signaling facilitates canonical Wnt signaling via inactivation of glycogen synthase kinase-3beta in osteoblastic Saos-2 cells. J Cell Biochem 104, 304-317.

43. Swiatek, W., Kang, H., Garcia, B. A., Shabanowitz, J., Coombs, G. S., Hunt, D. F. and Virshup, D. M. 2006. Negative regulation of LRP6 function by casein kinase I epsilon phosphorylation. J Biol Chem 281, 12233-12241.

44. Tamai, K., Zeng, X., Liu, C., Zhang, X., Harada, Y., Chang, Z. and He, X. 2004. A mechanism for Wnt coreceptor activation. Mol Cell 13, 149-156.

45. Taurin, S., Sandbo, N., Qin, Y., Browning, D. and Dulin, N. O. 2006. Phosphorylation of beta-catenin by cyclic AMP-dependent protein kinase. J Biol Chem 281, 9971-9976.

46. Tian, Q., Feetham, M. C., Tao, W. A., He, X. C., Li, L., Aebersold, R. and Hood, L. 2004. Proteomic analysis identifies that 14-3-3zeta interacts with beta-catenin and facilitates its activation by Akt. Proc Natl Acad Sci USA 101, 1537015375 .

47. Wallingford, J. B. and Habas, R. 2005. The developmental biology of Dishevelled: an enigmatic protein governing cell fate and cell polarity. Development 132, 4421-4436.

48. Wan, M., Yang, C., Li, J., Wu, X., Yuan, H., Ma, H., He, X., Nie, S., Chang, C. and Cao, X. 2008. Parathyroid hormone signaling through low-density lipoprotein-related protein 6. Genes Dev 22, 2968-2979.

49. Wang, S. and Jones, K. A. 2006. CK2 controls the recruitment of Wnt regulators to target genes in vivo. Curr Biol 16, 2239-2244.

50. Willert, K., Brink, M., Wodarz, A., Varmus, H. and Nusse, R. 1997. Casein kinase 2 associates with and phosphorylates dishevelled. EMBO J 16, 3089-3096.

51. Willert, K. and Jones, K. A. 2006. Wnt signaling: is the party in the nucleus? Genes Dev 20, 1394-1404.

52. Willert, K., Shibamoto, S. and Nusse, R. 1999. Wnt-induced dephosphorylation of axin releases beta-catenin from the axin complex. Genes Dev 13, 1768-1773.

53. Wu, X., Tu, X., Joeng, K. S., Hilton, M. J., Williams, D. A. and Long, F. 2008. Rac1 activation controls nuclear localization of beta-catenin during canonical Wnt signaling. Cell 133, 340-353.

54. Xing, Y., Clements, W. K., Kimelman, D. and Xu, W. 2003. Crystal structure of a beta-catenin/axin complex suggests a mechanism for the beta-catenin destruction complex. Genes Dev 17, 2753-2764.

55. Yamamoto, H., Kishida, S., Kishida, M., Ikeda, S., Takada, S. and Kikuchi, A. 1999. Phosphorylation of axin, a Wnt signal negative regulator, by glycogen synthase kinase-3beta regulates its stability. J Biol Chem 274, 10681-10684.

56. Yost, C., Torres, M., Miller, J. R., Huang, E., Kimelman, D. and Moon, R. T. 1996. The axis-inducing activity, stability, and subcellular distribution of beta-catenin is regulated in Xenopus embryos by glycogen synthase kinase 3. Genes Dev 10, 1443-1454.

57. Zeng, X., Huang, H., Tamai, K., Zhang, X., Harada, Y., Yokota, C., Almeida, K., Wang, J., Doble, B., Woodgett, J., Wynshaw-Boris, A., Hsieh, J. C. and He, X. 2008. Initiation of Wnt signaling: control of Wnt coreceptor Lrp6 phosphorylation/activation via frizzled, dishevelled and axin functions. Development 135, 367-375.

58. Zeng, X., Tamai, K., Doble, B., Li, S., Huang, H., Habas, R., Okamura, H., Woodgett, J. and He, X. 2005. A dual-kinase mechanism for Wnt co-receptor phosphorylation and activation. Nature 438, 873-877.

59. Zhang, J., Yang, P. L. and Gray, N. S. 2009. Targeting cancer with small molecule kinase inhibitors. Nat Rev Cancer 9, 28-39.

60. Zhang, L., Jia, J., Wang, B., Amanai, K., Wharton, K. A., Jr. and Jiang, J. 2006. Regulation of wingless signaling by the CKI family in Drosophila limb development. Dev Biol 299, 221-237. 
초록 : Wnt/ $\beta$-catenin 신호를 조절하는 인산화 효소

신은영 ${ }^{1,2} \cdot$ 박창균 $^{1} \cdot$ 홍연희 ${ }^{1} \cdot$ 김건화 ${ }^{1,{ }_{\star}}$

('한국기초과학지원연구원 생명과학연구부, ${ }^{2}$ 과학기술연합대학원 대학교 기능유전체학과)

Wnt/ $\beta$-catenin 신호는 세포의 운명 결정, 증식, 분화 등을 조절하는 척추 동물 배아 발생과 성체의 항상성 유 지에 필수적인 세포신호전달경로이다. 이러한 Wnt/ $\beta$-catenin의 비정상적인 조절에 의해 선천적 기형, 암, 대사 질환 등을 비롯한 다양한 질병이 유발된다. 이를 바탕으로 최근 Wnt/ $\beta$-catenin 신호의 조절을 통한 암을 비롯한 질병의 치료를 위한 연구가 활발히 진행되고 있다. 따라서 $\mathrm{Wnt} / \beta$-catenin 신호를 조절하는 인자의 발굴 및 자세 한 작용 기전에 대한 연구가 절실히 필요하다. 본 총설에서는 최근 새롭게 알려진 Wnt/ $\beta$-catenin 신호 조절 기작 에 대해 설명하고, 현재까지 알려진 Wnt/ $\beta$-catenin을 조절하는 인산화 효소(kinase)의 종류와 작용 기전과 새로 운 약물 타겟으로 전망을 알아 보고자 한다. 